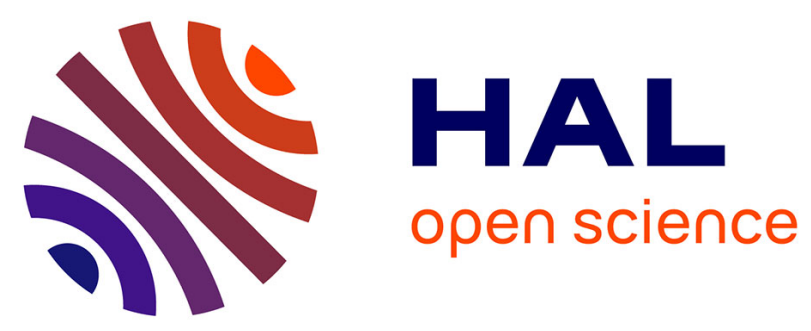

\title{
Urinary excretion of purine derivatives, microbial protein synthesis, nitrogen use, and ruminal fermentation in sheep and goats fed diets of different quality 1
}

M. Carro, Gonzalo Cantalapiedra-Hijar, M. Ranilla, E. Molina-Alcaide

\section{To cite this version:}

M. Carro, Gonzalo Cantalapiedra-Hijar, M. Ranilla, E. Molina-Alcaide. Urinary excretion of purine derivatives, microbial protein synthesis, nitrogen use, and ruminal fermentation in sheep and goats fed diets of different quality1. Journal of Animal Science, 2012, 90 (11), pp.3963-3972. 10.2527/jas.20114577 . hal-02455835

\section{HAL Id: hal-02455835 \\ https://hal.science/hal-02455835}

Submitted on 29 May 2020

HAL is a multi-disciplinary open access archive for the deposit and dissemination of scientific research documents, whether they are published or not. The documents may come from teaching and research institutions in France or abroad, or from public or private research centers.
L'archive ouverte pluridisciplinaire HAL, est destinée au dépôt et à la diffusion de documents scientifiques de niveau recherche, publiés ou non, émanant des établissements d'enseignement et de recherche français ou étrangers, des laboratoires publics ou privés. 


\section{JOURNAL OF ANIMAL SCIENCE \\ The Premier Journal and Leading Source of New Knowledge and Perspective in Animal Science}

Urinary excretion of purine derivatives, microbial protein synthesis, nitrogen use, and ruminal fermentation in sheep and goats fed diets of different quality

M. D. Carro, G. Cantalapiedra-Hijar, M. J. Ranilla and E. Molina-Alcaide

J ANIM SCI 2012, 90:3963-3972.

doi: 10.2527/jas.2011-4577 originally published online May 14, 2012

The online version of this article, along with updated information and services, is located on the World Wide Web at:

http://www.journalofanimalscience.org/content/90/11/3963 


\title{
Urinary excretion of purine derivatives, microbial protein synthesis, nitrogen use, and ruminal fermentation in sheep and goats fed diets of different quality ${ }^{1}$
}

\author{
M. D. Carro, ${ }^{*} \uparrow$ G. Cantalapiedra-Hijar, $\$$ M. J. Ranilla, ${ }^{*} \uparrow$ and E. Molina-Alcaide ${ }^{2}$ \\ *Departamento de Producción Animal, Universidad de León 24071, Spain; †Instituto de Ganadería \\ de Montaña (CSIC-ULE), Finca Marzanas s/n 24346 Grulleros, León, Spain; and \$Estación Experimental \\ del Zaidín (EEZ-CSIC), Professor Albareda 1, 18008, Granada, Spain
}

\begin{abstract}
The objective of this study was to compare $\mathrm{N}$ balance, microbial $\mathrm{N}$ flow (MNF) estimated from purine derivatives (PD) urinary excretion, and its variation when estimated using purine bases: $\mathrm{N}$ ratios in liquid associated bacteria (LAB) from models reported in the literature (MNF - response models) or measured ratios in liquid and solid-associated bacterial (SAB) pellets (MNF-LAB $+\mathrm{SAB}$ ), diet digestibility, and rumen fermentation variables in sheep and goats fed 3 different practical, quality diets to study interspecies differences concerning $\mathrm{N}$ use as accurately as possible. Four mature female Merino sheep and 4 mature female Granadina goats, each fitted with a ruminal cannula, were used in $3 \times 3$ Latin square design with an extra animal. Two experimental diets had a forage-to-concentrate ratio of 70:30 (DM basis) with alfalfa hay (ALC) or grass hay (GRC) as forage, and the third diet contained 70\% concentrate and $30 \%$ alfalfa hay (CAL). All animals were fed the diets at a daily rate of $56 \mathrm{~g} / \mathrm{kg} \mathrm{BW}^{0.75}$ to minimize feed selection. Digestibility of nutrients was similar $(P=0.16$ to 0.88$)$ in the 2 species, but some animal species $\times$ diet interactions $(P=0.01$ to 0.04$)$
\end{abstract}

were detected. There were small differences between the fermentation patterns of both animal species. Goats showed decreased VFA concentrations $(P=0.005)$ and butyrate proportions $(P=0.04)$, and greater acetate proportions $(P=0.02)$ compared with sheep, whereas $\mathrm{N}$ intake and percentage of $\mathrm{N}$ intake excreted in feces were similar in both species $(P=0.58$ and 0.15 , respectively), the percentage excreted via the urine was greater in goats compared with sheep $(P<0.001)$. As a consequence, sheep had greater $(P<0.001) \mathrm{N}$ retention than goats (averaged across diets, $32.6 \%$ and $16.1 \%$ of $\mathrm{N}$ intake, respectively). There were no differences ( $P$ $=0.95)$ between animal species in total PD excretion, but goats showed a greater excretion of allantoin $(P=$ $0.01)$ and decreased excretion of xanthine $(P=0.008)$ and hypoxanthine $(P=0.007)$ compared with sheep. In general, differences between sheep and goats were more pronounced for the medium-quality diet (GRC) compared with those of high-quality diet (ALC and CAL). The greater urinary losses in goats would indicate a greater contribution of goats to $\mathrm{N}$ environmental contamination compared with sheep.

Key words: bacterial pellets, goats, microbial synthesis, nitrogen, purine derivatives, sheep

(C) 2012 American Society of Animal Science. All rights reserved.

J. Anim. Sci. 2012.90:3963-3972 doi:10.2527/jas2011-4577

\section{INTRODUCTION}

Digestive capacity in sheep and goats fed the same diets has been extensively investigated, although re-

\footnotetext{
${ }^{1}$ Funding was provided by the Spanish Ministerio de Ciencia y Tecnología (projects AGL2004-04755-C02-01 and AGL200404755-C02-02). G. Cantalapiedra-Hijar gratefully acknowledges the receipt of a scholarship of Formacion de Personal Universitario (FPU) from the Ministerio de Educacion y Ciencia (MEC) of Spain (AP2004-1908).

${ }^{2}$ Corresponding author: molina@eez.csic.es

Received August 10, 2011.

Accepted March 14, 2012.
}

sults are inconsistent (Devendra, 1989). Most comparative studies have focused on diet digestibility, rumen fermentation pattern, and digesta passage kinetics, whereas microbial protein synthesis and $\mathrm{N}$ balance have received much less attention, despite their influence on animal production performance. The $\mathrm{N}$ excretion represents an important source of environmental contamination from small ruminant farming systems (Tamminga, 1996), mainly in intensive (dairy) Mediterranean systems. Excretion of $\mathrm{N}$ in feces and urine depends mainly on the $\mathrm{N}$ content of the diet and its digestibility, but it also may vary with animal spe- 
cies (Devendra, 1989). Goats have shown reduced N losses compared with sheep in some studies (Bohra, 1980; Doyle et al., 1984), whereas, in other studies, they showed greater (Antoniou and Hadjipanayiotou, 1985; Al Jassim et al., 1991; Isac et al., 1994) or similar losses (Gihad, 1976; Doyle et al., 1984; Yáñez-Ruiz and Molina-Alcaide, 2007). These contrasting results would indicate that species differences in $\mathrm{N}$ use may vary with the diet.

Microbial N flow (MNF) to the duodenum can be estimated from the urinary excretion of purine derivatives (PD) and response models (RM) have been developed in sheep (Balcells et al., 1991; Chen et al., 1992) and goats (Belenguer et al., 2002; Mota et al., 2008). However, comparative studies in sheep and goats fed the same diets are very scarce (Yáñez et al., 2004ab; Fujihara et al., 2007) and their results are contrasting. Our hypothesis was that differences between sheep and goats in $\mathrm{N}$ use may be affected by the type of diet. The objective of this study was to compare N use and MNF in sheep and goats fed 3 different quality practical diets at the same amount of intake. The diets were formulated to be representative of those currently used in sheep and goats, and practical for feeding in some Mediterranean countries. Diets differed in their $\mathrm{N}$ and energy content with the objective of promoting different microbial protein synthesis.

\section{MATERIALS AND METHODS}

Animal management and sampling were carried out by trained personnel and animals were cared for and handled in accordance with the Spanish guidelines for experimental animal protection (Royal Decree $1201 / 2005$ of Oct. 10 on the protection of animals used for experimentation or other scientific purposes), in line with the European Convention for the Protection of Vertebrates used for Experimental and other Scientific Purposes (European Directive 86/609).

\section{Animals and Diets}

Four female Merino sheep $(54.4 \pm 3.05 \mathrm{~kg} \mathrm{BW})$ and 4 female Granadina goats $(46.0 \pm 1.30 \mathrm{~kg} \mathrm{BW})$, each fitted with a ruminal cannula, were used. All animals were nonpregnant and nonlactating adults between 2 and $3 \mathrm{yr}$ old. Animals were housed in individual pens and had continuous access to fresh water and vitamin-mineral block over the experimental period.

Three total mixed diets were formulated. Two experimental diets had a forage-to-concentrate ratio (on DM basis) of 70:30, with either alfalfa hay (ALC) or grass hay (GRC) as forage. The third diet contained $70 \%$ concentrate and 30\% alfalfa hay (CAL). The concentrate was based on barley, gluten feed, wheat middlings, soybean
Table 1. Chemical composition of the experimental diets ${ }^{1}$

\begin{tabular}{llll}
\hline \hline Item & \multicolumn{1}{c}{ GRC1 } & ALC1 & CAL1 \\
\hline $\mathrm{DM}, \%$ & 92.5 & 92.7 & 92.5 \\
$\mathrm{OM}, \%$ of DM & 92.7 & 91.3 & 91.3 \\
$\mathrm{CP},{ }^{2} \%$ of DM & 12.1 & 16.8 & 17.7 \\
$\mathrm{NDF}, \%$ of DM & 49.9 & 42.6 & 37.4 \\
$\mathrm{ADF}, \%$ of DM & 23.8 & 26.9 & 18.7 \\
$\mathrm{ME},{ }^{3} \mathrm{Mcal} / \mathrm{kg}$ of DM & 2.00 & 2.12 & 2.45 \\
$\mathrm{MP},{ }^{3} \mathrm{~g} / \mathrm{kg}$ of DM & 88 & 122 & 127 \\
$\mathrm{RDP},{ }^{4} \mathrm{~g} / \mathrm{kg}$ of DM & 8.4 & 12.8 & 12.6 \\
$\mathrm{RDP} / \mathrm{ME}$ & 4.2 & 6.0 & 5.1 \\
\hline
\end{tabular}

${ }^{1} \mathrm{GRC}=70: 30$ grass hay: concentrate; $\mathrm{ALC}=70: 30$ alfalfa hay:concentrate; $\mathrm{CAL}=70: 30$ concentrate:alfalfa hay. Feed proportions are given on DM basis.

${ }^{2}$ Calculated as $\mathrm{N} \times 6.25$.

${ }^{3}$ Estimated according to the NRC (2007).

${ }^{4} \mathrm{RDP}$ was estimated according to NRC (1985) and values were $0.69,0.76$, and $0.71 \mathrm{~g} / \mathrm{g}$ for diets GRC, ALC, and CAL, respectively.

meal, palmkern meal, wheat, corn, and mineral-vitamin premix in the proportions of $22 \%, 20 \%, 20 \%, 13 \%, 12 \%$, $5 \%, 5 \%$, and $3 \%$, respectively (DM basis). The alfalfa hay was a second cut, harvested at 30\% flowering stage, and it contained $91.3 \% \mathrm{DM}, 2.67 \% \mathrm{~N}, 46.6 \% \mathrm{NDF}$, and $33.1 \%$ ADF (DM basis). The grass hay consisted primarily (dry mass) of perennial ryegrass $(81 \%)$, red and white clover (11\%), and other grasses ( $8 \%)$. It was harvested at postflowering stage. It contained $93.3 \% \mathrm{DM}, 1.46 \% \mathrm{~N}$, $56.9 \% \mathrm{NDF}$, and $28.6 \%$ ADF (DM basis). The concentrate contained $91.4 \% \mathrm{DM}, 3.04 \% \mathrm{~N}, 33.5 \% \mathrm{NDF}$, and $12.5 \%$ ADF (DM basis). Chemical composition of diets is shown in Table 1. Expected MNF would be different as experimental diets have different energy and $\mathrm{N}$ content. During the sampling period, samples of diets and refusals were collected daily and composited weekly. Composited samples of refusals were based on daily amounts of refusals (if any) per animal. Refusals were analyzed to calculate the actual feed intake of each animal.

Diets were offered to animals twice daily (0800 and $1800 \mathrm{~h}$ ), in 2 equal portions, at a daily rate of $56 \mathrm{~g} \mathrm{DM} /$ $\mathrm{kg} \mathrm{BW}^{0.75}$ to minimize feed selection, compare animals of the 2 species on similar diet composition, and achieve the greatest intake possible. Intake was estimated to meet $1.2,1.3$, and 1.5 times the energy maintenance requirements of sheep (NRC, 2007) for GRC, ALC, and CAL diets, respectively; and 1.1, 1.1, and 1.3 for goats (Prieto et al., 1990). The expected intake was estimated to meet 1.8, 2.3, and 2.4 times the MP maintenance requirements of sheep (NRC, 2007) for GRC, ALC, and CAL diets, respectively; and 1.7, 2.4, and 2.6 for goats (NRC, 2007). The estimated values of RDP:ME ratios were 4.2, 6.0, and $5.1 \mathrm{~g} / \mathrm{Mcal}$, respectively. 


\section{Experimental Procedure and Sampling}

Within each animal species, the experimental design was a $3 \times 3$ Latin square ( 3 dietary treatments and 3 periods) with an extra animal. The extra animal was included to increase the degrees of freedom of the statistical analysis. Each 29-d experimental period consisted of $15 \mathrm{~d}$ of dietary adaptation and $13 \mathrm{~d}$ of sample and data collection.

On d 13, animals were moved to metabolism cages equipped for a separate collection of feces and urine. The cages were engineered to separate feces and urine into containers outside the cage. The floor of the rear part of the cage had $1.5 \mathrm{~cm}$ openings and feces and urine dropped on a device with a funnelshaped bottom and 2 openings. This device was provided with a screen and had a slope on which the feces ran down into a container fixed to 1 opening. The mesh of the screen was large enough to prevent urine from running the length of the screen and dripping into the feces. Urine was collected through the second opening. The unit was easily disassembled for cleaning. After giving the animals $2 \mathrm{~d}$ of adaptation to cages, feces and urine voided by each animal in $24 \mathrm{~h}$ were quantified for $6 \mathrm{~d}$. An aliquot (10\%) of total fecal output was collected each day for digestibility determination and dried at $55^{\circ} \mathrm{C}$ to constant weight before analysis. Urine was collected in a solution of $3.6 \mathrm{M} \mathrm{H}_{2} \mathrm{SO}_{4}$ to keep the $\mathrm{pH}<3$. The volume of urine at each sampling was determined and a subsample (20\%) was taken daily for each animal and frozen until analyzed for $\mathrm{N}$ and PD. Samples of feces and urine were pooled for each animal for the 6-d collection period. After sampling on d 21, animals were moved again to floor pens.

On d 23 and 25, $600 \mathrm{~g}$ of rumen contents were withdrawn from each animal at 0 and $4 \mathrm{~h}$ after the morning feeding. Rumen contents were squeezed through 4 layers of cheesecloth and solid digesta was combined with an equal volume of saline solution $(0.9 \% \mathrm{NaCl})$ at $38^{\circ} \mathrm{C}$, mixed gently, and squeezed again to remove residual, nonattached bacteria. The filtrate obtained at each sampling time was kept at $4^{\circ} \mathrm{C}$, pooled per animal, and used to isolate liquid-associated bacteria (LAB) by differential centrifugation (Ranilla and Carro, 2003). The solid digesta was treated with saline solution $(0.9 \% \mathrm{NaCl})$ containing $0.1 \%$ methylcellulose, as described by Ranilla and Carro (2003), before isolation of solid-associated bacteria (SAB). In each period, bacterial pellets were composited to have 2 pellets per animal (1 SAB and $1 \mathrm{LAB}$ ). Bacterial pellets (LAB and $\mathrm{SAB}$ ) were lyophilized and ground to a fine powder with a mortar and pestle. After grinding and within each period, bacterial pellets were composited to have 2 pellets per animal (1 SAB and $1 \mathrm{LAB}$ ) before analysis of $\mathrm{N}$ and purine bases (PB) content.

On d 27 and 29, rumen content samples (200 g) were taken through the cannula of each animal at 0 and $4 \mathrm{~h}$ after the morning feeding. Rumen content was strained through 4 layers of cheesecloth and the $\mathrm{pH}$ of the fluid was immediately measured. Five milliliters of fluid was added to $5 \mathrm{~mL}$ of deproteinizing solution ( $100 \mathrm{~g}$ of metaphosphoric acid and $0.6 \mathrm{~g}$ of crotonic acid per liter) for VFA analysis and $2 \mathrm{~mL}$ was added to $2 \mathrm{~mL} 0.5 \mathrm{M} \mathrm{HCl}$ for $\mathrm{NH}_{3}-\mathrm{N}$ determination. Samples were composited by animal and sampling day before analysis.

During the sampling period, samples of diets and refusals were collected daily ( $13 \mathrm{~d}$ for each experimental period) and composited. Composited samples were thoroughly mixed and a subsample was taken and analyzed in each period. Samples were dried at $55^{\circ} \mathrm{C}$ in an oven for $48 \mathrm{~h}$ and ground using a Culatti grinder (model DFH 48 , Culatti, Zurich, Switzerland) with a 1-mm screen before chemical analyses.

\section{Analytical Procedures}

Procedures for analysis of DM, ash, N, NDF, ADF, VFA, and $\mathrm{NH}_{3}-\mathrm{N}$ have been described previously (Molina-Alcaide et al., 2010). Urinary PD (allantoin, hypoxanthine, uric acid, and xanthine) were determined following the procedures described by Balcells et al. (1991), using HPLC analysis. The PB concentration in LAB and $\mathrm{SAB}$ pellets was quantified by HPLC after acid hydrolysis with $2 \mathrm{~mL}$ of $2 \mathrm{M}$ perchloric acid at $100^{\circ} \mathrm{C}$ for $1 \mathrm{~h}$ (Martín-Orúe et al., 1995).

\section{Calculations and Statistical Analyses}

Animals were weighed at the beginning, middle, and end of each experimental period, and the mean BW was calculated from the 3 measurements. The MNF at the duodenum in goats was estimated from the daily urinary excretion of PD, using the RM (MNF-RM) proposed by Belenguer et al. (2002) and stated for adult, nonlactating and not pregnant goats. In sheep, MNF was estimated by using RM of Balcells et al. (1991) and Chen et al. (1992). Because there were no differences $(P=0.36)$ in MNF values derived from the $2 \mathrm{RM}$, we decided to use the MNF estimations obtained with the model of Balcells et al. (1991), as this model and the one of Belenguer et al. (2002) were developed by the same group, using the same methodology. The MNF was also estimated from the daily urinary excretion of PD, assuming values of recovery of purines flowing to the duodenum as PD excreted in urine of 0.802 for sheep (Balcells et al., 1991) and 0.760 for goats (Belenguer et al., 2002), and the PB:N ratios determined in our study in LAB (MNFLAB) or SAB (MNF-SAB) pellets. Finally, the average PB:N ratios of MNF-LAB and MNF-SAB were also calculated (MNF-LAB+SAB). Urinary PD excretion was corrected for the endogenous contribution of $\mathrm{PD}$, using 
a value of $158 \mu \mathrm{mol} / \mathrm{kg} \mathrm{BW}^{0.75}$ for sheep (Chen et al., 1990; Balcells et al., 1991) and $202 \mu \mathrm{mol} / \mathrm{kg} \mathrm{BW}^{0.75}$ for goats (Belenguer et al., 2002; Jetana, 2005).

Data were analyzed as a mixed model using the PROC MIXED (SAS Inst. Inc., Cary, NC). The effects of animal species (AS), diet, period, and AS $\times$ diet interaction were considered fixed, and animal effect was considered random. Ruminal variables $\left(\mathrm{pH}, \mathrm{VFA}\right.$, and $\mathrm{NH}_{3}-$ $\mathrm{N})$ were analyzed as repeated measures. The statistical model used included AS, diet, period, sampling time, AS $\times$ diet, AS $\times$ sampling time, diet $\times$ sampling time, and AS $\times$ diet $\times$ sampling time as fixed effects, and animal as a random effect. Effects were declared significant at $P<$ 0.05 and $P$-values between 0.05 and 0.10 were considered as a trend. When a significant AS $\times$ diet was detected, an analysis of variance was performed independently for each diet to analyze AS differences. All values are reported as means and there were 4 observations for each AS and parameter. Data on microbial N (MNF-LAB, MNF-SAB, and MNF-LAB+SAB) were compared with RM calculations (MNF-RM), using paired Student's $t$ test within each animal species $(n=12)$.

\section{RESULTS AND DISCUSSION}

The diets used in the study were formulated to differ in their $\mathrm{N}$ and energy content, with the objective of promoting different $\mathrm{MNF}$ and $\mathrm{PD}$ excretion. Initial $\mathrm{BW}$ tended $(P=0.06)$ to be greater for sheep compared with goats, but BW was not changed through the trial in any species $(P=0.36$ and 0.47 for sheep and goats, respectively). Mean BW at the end of periods 1, 2, and 3 were, respectively, $54.5,53.9$, and $54.6 \mathrm{~kg}$ for sheep, and 46.4 , 45.9 , and $46.5 \mathrm{~kg}$ for goats.

\section{Intake and Digestibility}

As shown in Table 2, mean values for DM intakes ranged from 46.0 to $54.7 \mathrm{~g} / \mathrm{kg} \mathrm{BW}^{0.75}$. In sheep, DM intake values for ALC and CAL diets were close to the amount offered, but GRC intake was less (50.3 g DM/ $\mathrm{kg} \mathrm{BW}^{0.75}$ ). In goats, only CAL intake was close to the amount offered, whereas GRC and ALC intakes were less (46.0 and $50.6 \mathrm{~g} \mathrm{DM} / \mathrm{kg} \mathrm{BW}^{0.75}$, respectively). The reduced $(P<0.05)$ intake of GRC compared with ALC and CAL observed in both species may have been due to a reduced palatability of grass hay compared with alfalfa hay and concentrate, and to differences in chemical composition and digestibility among feeds. Dry matter intake tended $(P=0.09)$ to be greater in sheep compared with goats. Although the study was designed to avoid diet selection, the selective behavior of goats was not completely inhibited as indicated by the greater CP $(P$ $=0.04)$ and decreased $\operatorname{NDF}(P=0.007)$ and $\operatorname{ADF}(P=$
$0.02)$ intake shown by goats compared with sheep (Table 2). A significant $(P=0.04)$ AS $\times$ diet interaction was detected for ADF intake, whereas ADF intake was similar in both animal species for diets GRC $(P=0.13)$ and $\mathrm{CAL}(P=0.63)$, ADF intake in goats was less $(P=$ 0.04) compared with sheep for ALC diet.

No differences ( $P=0.16$ to 0.88 ) between sheep and goats were found in apparent total tract digestibility or any of the considered nutrients (Table 2). These results are consistent with those from earlier studies (Isac et al., 1994; Molina Alcaide et al., 2000; Ranilla et al., 2001) and suggest that no differences in total tract digestibility might be expected between sheep and goats fed medium to good quality diets. In both animal species, DM, OM, and $\mathrm{CP}$ digestibilities were greater $(P<0.05)$ for CAL compared with GRC diet, whereas ALC diet showed intermediate values. However, significant AS $\times$ diet interactions ( $P=0.01$ to 0.04$)$ were detected for all digestibility values and differences in digestibility were analyzed independently for each diet. There were no differences between sheep and goats in any digestibility value for CAL diet $(P=0.32,0.37,0.90$, and 0.13 for DM, OM, $\mathrm{CP}$, and NDF digestibility, respectively). Sheep fed the GRC diet tended $(P=0.07)$ to have greater DM and OM digestibility compared with goats, but goats had greater $(P=0.03)$ CP digestibility than sheep. Although no differences $(P=0.13$ to 0.45$)$ between AS was observed in NDF digestibility for any diet, NDF digestibility in sheep was numerically greater for diet ALC and decreased for diet CAL compared with goats. These variable differences in NDF digestibility between diets are difficult to explain, but they could be related to different microbial populations in the rumen of sheep and goats.

\section{Ruminal Fermentation}

In agreement with previous results (Isac et al., 1994; Molina Alcaide et al., 2000), ruminal $\mathrm{pH}$ values were similar $(P=0.20)$ in both species (Table 3). An AS $\times$ diet interaction $(P=0.03)$ was detected for $\mathrm{NH}_{3}-\mathrm{N}$ concentrations and results were analyzed for each diet independently. No differences between AS were detected for diets ALC and CAL $(P=0.39$ and 0.16 , respectively), but goats tended $(P=0.07)$ to have greater $\mathrm{NH}_{3}-\mathrm{N}$ concentrations compared with sheep for GRC diet. Others (Domingue et al., 1991; Li et al., 2008) have also reported no interspecies differences in $\mathrm{NH}_{3}-\mathrm{N}$ concentrations when animals were fed medium to good quality forages.

For all diets, mean VFA concentrations in the rumen of sheep were greater $(P<0.005)$ compared with those found in goats (Table 3 ), which may be partly due to the tendency for sheep to have greater DM intake than goats (Table 2). However, DM, OM, and NDF intake for CAL diet was similar in the 2 AS and total VFA con- 
Table 2. Effects of animal species (AS) and dietary treatments on intake and digestibility mean values in sheep and goats $(n=4)$

\begin{tabular}{|c|c|c|c|c|c|c|c|c|}
\hline \multirow[b]{2}{*}{ Item } & \multirow[b]{2}{*}{ AS } & \multicolumn{3}{|c|}{ Diet $^{1}$} & \multirow[b]{2}{*}{ SEM } & \multicolumn{3}{|c|}{$P$-value ${ }^{2}$} \\
\hline & & $\mathrm{GRC}^{1}$ & $\mathrm{ALC}^{1}$ & $\mathrm{CAL}^{1}$ & & $\mathrm{AS}$ & Diet & $\mathrm{AS} \times$ diet \\
\hline DMI, g/d & Sheep & 986 & 1061 & 1084 & 29.7 & 0.06 & 0.14 & 0.59 \\
\hline \multicolumn{9}{|l|}{ Intake, $\mathrm{g} / \mathrm{kg} \mathrm{BW} \mathrm{C}^{0.75}$} \\
\hline $\mathrm{DM}$ & Sheep & 50.3 & 54.6 & 54.7 & 1.55 & 0.09 & 0.006 & 0.23 \\
\hline $\mathrm{OM}$ & Goat & 42.5 & 45.7 & 49.5 & & & & \\
\hline \multirow[t]{2}{*}{$\mathrm{CP}^{3}$} & Sheep & 5.93 & 8.64 & 9.96 & 0.304 & 0.04 & $<0.001$ & 0.11 \\
\hline & Goat & 5.76 & 9.83 & 10.91 & & & & \\
\hline \multirow[t]{2}{*}{ NDF } & Sheep & 23.4 & 23.1 & 20.6 & 0.63 & 0.007 & $<0.001$ & 0.13 \\
\hline & Goat & 22.2 & 20.5 & 20.1 & & & & \\
\hline \multicolumn{9}{|c|}{ Apparent total tract digestibility, $\%$} \\
\hline \multirow[t]{2}{*}{$\mathrm{DM}$} & Sheep & 67.4 & 69.5 & 71.5 & 0.95 & 0.49 & $<0.001$ & 0.04 \\
\hline & Goat & 65.6 & 66.9 & 74.2 & & & & \\
\hline \multirow[t]{2}{*}{$\mathrm{OM}$} & Sheep & $69.8^{\mathrm{b}}$ & 72.5 & 74.9 & 0.91 & 0.16 & $<0.001$ & 0.03 \\
\hline & Goat & $67.6^{\mathrm{a}}$ & 69.1 & 77.0 & & & & \\
\hline \multirow[t]{2}{*}{$\mathrm{CP}$} & Sheep & 64.9 & $75.4^{\mathrm{a}}$ & 77.5 & 0.96 & 0.16 & $<0.001$ & 0.02 \\
\hline & Goat & 63.2 & $80.3^{\mathrm{b}}$ & 79.2 & & & & \\
\hline \multirow[t]{2}{*}{ NDF } & Sheep & 60.6 & 59.4 & 56.8 & 3.85 & 0.63 & 0.02 & 0.01 \\
\hline & Goat & 62.6 & 52.5 & 64.1 & & & & \\
\hline $\mathrm{ADF}$ & Sheep & 55.3 & 56.6 & 50.7 & 2.48 & 0.88 & 0.13 & 0.07 \\
\hline
\end{tabular}

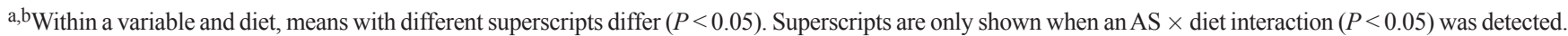

${ }^{1} \mathrm{GRC}=70: 30$ grass hay:concentrate; $\mathrm{ALC}=70: 30$ alfalfa hay: concentrate; $\mathrm{CAL}=70: 30$ concentrate:alfalfa hay.

${ }^{2}$ When an AS $\times$ diet interaction $(P<0.05)$ was detected, differences between AS were analyzed independently for each diet. The $P$-values of ANOVA for GRC, ALC, and CAL diets were: 0.13, 0.04, and 0.63 for ADF intake, 0.23, 0.07, and 0.32 for DM digestibility, 0.04, 0.07, and 0.37 for OM digestibility, 0.74, 0.03 , and 0.90 for CP digestibility, and $0.43,017$, and 0.13 for NDF digestibility, respectively.

${ }^{3}$ Calculated as $\mathrm{N} \times 6.25$.

${ }^{4}$ Estimated according to NRC (2007).

centrations in goats were 0.64 of those in sheep, which would indicate interspecies differences in the rate of VFA production or absorption and digesta passage rates, or both (Ranilla et al., 2001; Tsiplakou et al., 2011). Mean proportions of propionate and other VFA (calculated as the sum of isobutyrate, isovalerate and valerate) were similar ( $P=0.18$ and 0.19 , respectively) in the $2 \mathrm{AS}$, but goats had greater mean acetate $(P=0.02)$ and acetate:propionate ratios $(P=0.04)$, as well as decreased $(P=0.04)$ mean butyrate proportions compared with sheep. The observed differences in VFA concentration and profile may indicate interspecies differences in ruminal microbial composition. The effects of the type of diet on interspecies differences on the VFA profile are not clear in the literature. And in our study, AS $\times$ diet interactions ( $P=0.003$ to 0.004$)$ were observed for molar proportions of propionate and other VFA, and for the acetate:propionate ratio. Goats had lower $(P$ $=0.04)$ propionate proportions and greater $(P=0.03)$ acetate:propionate ratios than sheep for GRC diet, but values for diets ALC and CAL were similar $(P=0.35$ to $0.96)$. Goats also had decreased $(P=0.002)$ proportions of other VFA compared with sheep when both AS were fed the diet ALC, but no differences were observed for diets GRC and CAL ( $P=0.46$ to 0.85$)$. In general, little interspecies differences in VFA profiles have been found in several studies (García et al., 1994; Molina-Alcaide et al., 1997; Yáñez-Ruiz et al., 2004a; Li et al., 2008).

\section{Nitrogen Balance}

There were no differences $(P=0.58)$ between the 2 AS in mean daily $\mathrm{N}$ intake $(\mathrm{g} / \mathrm{d})$, but goats showed greater $(P=0.04) \mathrm{N}$ intakes compared with sheep when expressed 
Table 3. Effects of animal species (AS) and dietary treatments on mean values of ruminal fermentation characteristics in sheep and goats $(n=4)$

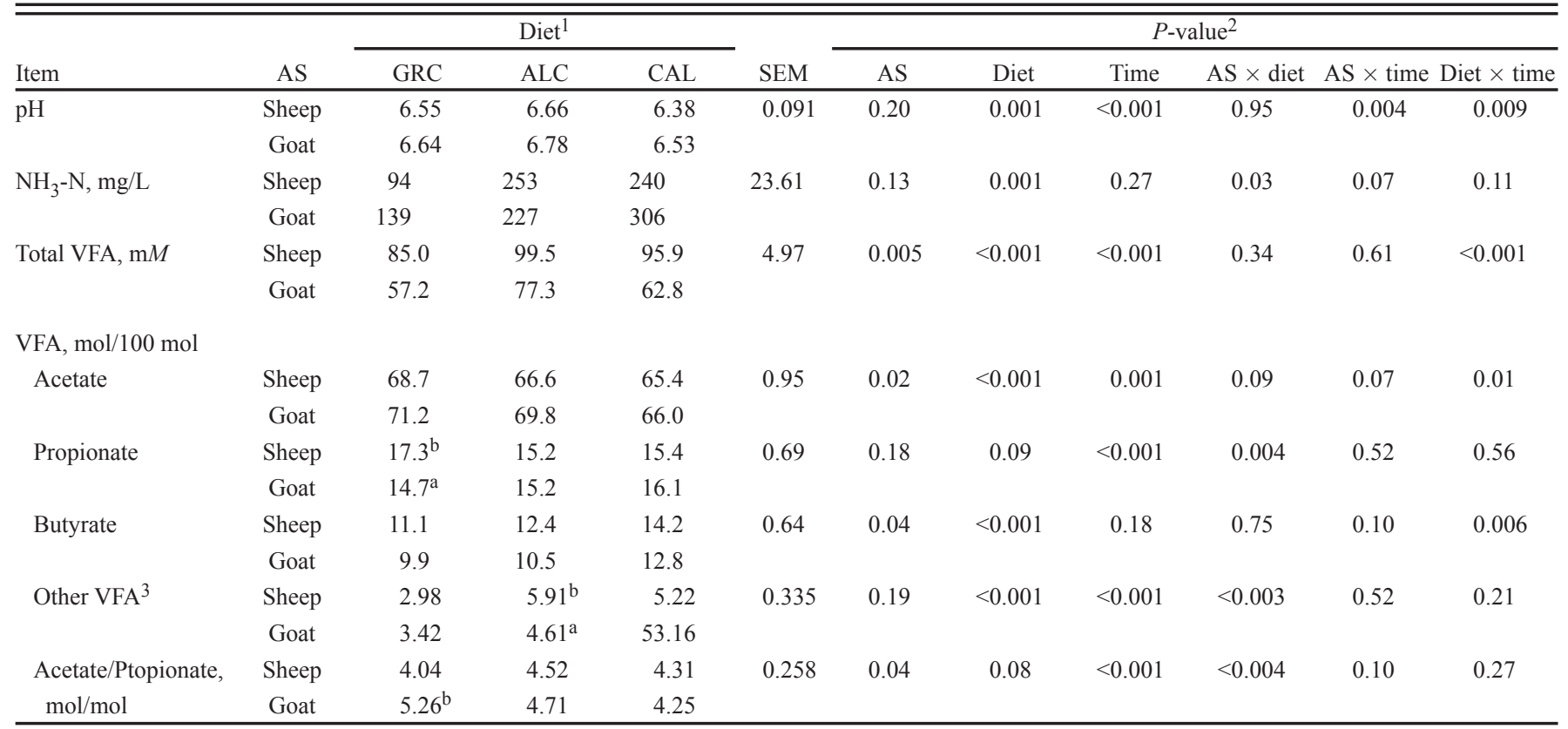

a,b Within a parameter and diet, means with different superscripts differ $(P<0.05)$. Superscripts are only shown when an AS $\times$ diet interaction $(\mathrm{P}<0.05)$ was detected.

${ }^{1} \mathrm{GRC}=70: 30$ grass hay: concentrate; $\mathrm{ALC}=70: 30$ alfalfa hay:concentrate $\mathrm{CAL}=70: 30$ concentrate:alfalfa hay.

${ }^{2}$ When an AS $\times$ diet interaction $(P<0.05)$ was detected, differences between AS were analyzed independently for each diet. The $P$-values of ANOVA for GRC, ALC, and CAL diets were: $0.07,0.39$, and 0.16 for $\mathrm{NH}_{3}-\mathrm{N}, 0.04,0.96$, and 0.35 for propionate, $0.46,0.002$, and 0.85 for other VFA, and $0.03,0.35$, and 0.81 for acetate/propionate ratio, respectively. AS $\times$ diet $\times$ time interactions were not significant $(P>0.005)$.

${ }^{3}$ Calculated as the sum of isobutyrate, isovalerate, and valerate.

as gram per kilogram BW $\mathrm{BW}^{0.75}$ (averaged across diets, 1.42 and $1.31 \mathrm{~g} / \mathrm{kg} \mathrm{BW}^{0.75}$; Table 4). Compared with sheep, goats showed greater $(P<0.001)$ mean amounts of $\mathrm{N}$ excreted in the urine but tended $(P=0.05)$ to excrete lower total amounts of $\mathrm{N}$ via feces. An $\mathrm{AS} \times$ diet interaction $(P$ $=0.03$ ) was detected for fecal $\mathrm{N}$ excretion expressed as percentage of $\mathrm{N}$ intake and data were reanalyzed by diet. Goats showed decreased $(P=0.03)$ fecal N losses compared with sheep for ALC diet, but no differences were observed for GRC $(P=0.42)$ and CAL $(P=0.38)$ diets.

The mean value for the percentage of $\mathrm{N}$ intake excreted in urine was greater $(P<0.001)$ in goats than sheep $(58.5 \%$ and $40.2 \%$, respectively, averaged across diets), resulting in reduced $(P \leq 0.001)$ mean $\mathrm{N}$ retention in goats compared with sheep, expressed either as $\mathrm{g} / \mathrm{d}(8.41$ and $4.32 \mathrm{~g} / \mathrm{d}$, respectively, averaged across diets) or percentage of $\mathrm{N}$ intake (32.6\% and $16.1 \%)$. There were no AS x diet interactions $(P>0.05)$ for mean $\mathrm{N}$ retention, but an AS $\mathrm{x}$ diet interaction $(P=0.04)$ was detected for urinary $\mathrm{N}$ excretion expressed as $\mathrm{g} / \mathrm{d}$ and data were reanalyzed by diet. Goats showed greater $\mathrm{N}$ urinary losses compared with sheep for all diets $(P=0.01,0.002$ and 0.008 for GRC, ALC and CAL diets, respectively). As a proportion of $\mathrm{N}$ intake, retained $\mathrm{N}$ ranged from 29.5 to $36.8 \%$ for sheep and from 9.4 to $22.4 \%$ for goats, values which were in the range of those previously reported in sheep (Domingue et al., 1991; Carro et al., 2000) and goats (Domingue et al., 1991; Yáñez-Ruiz and MolinaAlcaide, 2007, 2008) fed diets with variable $\mathrm{N}$ content at about maintenance. Although our results agree with others in the literature, the mean $\mathrm{N}$ retention $(\mathrm{g} / \mathrm{d})$ values were unexpectedly high for animals fed slightly above maintenance. Nitrogen losses during sampling collection seem improbable, as urine $\mathrm{pH}$ was checked every $12 \mathrm{~h}$ to assure values below 3.0 to prevent ammonia losses and no urine or feces losses were noticed, but they cannot be completely discarded. An alternative explanation is that $\mathrm{N}$ has been retained in wool (sheep) and hair (goats), but the daily wool and hair growth do not fully explain the observed $\mathrm{N}$ retention.

The greater urinary $\mathrm{N}$ excretion observed in goats might be the consequence of greater $\mathrm{N}$ absorption from the rumen compared with sheep followed by greater postabsorptive losses of $\mathrm{N}$ as a consequence of an imbalance between the availability of NE and AA in tissues (Tamminga, 1996). In fact, goats had decreased $\mathrm{N}$ retained per kilogram of digestible OM intake compared with sheep for all diets (12.0 and $7.2 \mathrm{~g} / \mathrm{kg}$ digestible OM intake, respectively, averaged across diets). Ruminal $\mathrm{NH}_{3}-\mathrm{N}$ concentrations were numerically greater in goats than in sheep for GRC and CAL, which would support the hypothesis of greater $\mathrm{CP}$ degradation in the rumen of goats. Alternatively, greater maintenance $\mathrm{N}$ requirements in goats compared with sheep would help to explain the 
Table 4. Effects of animal species (AS) and dietary treatments on $N$ utilization mean values in sheep and goats $(n=4)$

\begin{tabular}{|c|c|c|c|c|c|c|c|c|}
\hline \multirow[b]{2}{*}{ Item } & \multirow[b]{2}{*}{ AS } & \multicolumn{3}{|c|}{ Diet $^{1}$} & \multirow[b]{2}{*}{ SEM } & \multicolumn{3}{|c|}{$\boldsymbol{P}$-value ${ }^{2}$} \\
\hline & & GRC & ALC & CAL & & AS & Diet & $\mathrm{AS} \times \operatorname{diet}$ \\
\hline \multicolumn{9}{|l|}{$\mathrm{N}$ intake } \\
\hline $\mathrm{g} / \mathrm{d}$ & Goat & 16.1 & 27.8 & 31.4 & & & & \\
\hline \multirow[t]{2}{*}{$\mathrm{g} / \mathrm{kg} \mathrm{BW}^{0.75}$} & Sheep & 0.95 & 1.38 & 1.60 & 0.049 & 0.04 & $<0.001$ & 0.11 \\
\hline & Goat & 0.92 & 1.58 & 1.75 & & & & \\
\hline $\mathrm{g} / \mathrm{d}$ & Goat & $8.7^{\mathrm{b}}$ & $16.1^{\mathrm{b}}$ & $19.7^{\mathrm{b}}$ & & & & \\
\hline \multirow[t]{2}{*}{$\%$ of $\mathrm{N}$ intake } & Sheep & 35.6 & 39.1 & 46.0 & 2.24 & $<0.001$ & 0.006 & 0.84 \\
\hline & Goat & 54.6 & 58.1 & 62.7 & & & & \\
\hline \multicolumn{9}{|l|}{ Fecal $\mathrm{N}$ excretion } \\
\hline $\mathrm{g} / \mathrm{d}$ & Sheep & 6.52 & 6.55 & 7.09 & 0.292 & 0.05 & 0.07 & 0.66 \\
\hline \multicolumn{9}{|l|}{$\mathrm{N}$ retention } \\
\hline \multirow[t]{2}{*}{$\mathrm{g} / \mathrm{d}$} & Sheep & 5.48 & 9.85 & 9.91 & 0.626 & $<0.001$ & $<0.001$ & 0.67 \\
\hline & Goat & 1.51 & 6.23 & 5.21 & & & & \\
\hline \multirow[t]{2}{*}{$\%$ of $\mathrm{N}$ intake } & Sheep & 29.5 & 36.8 & 31.5 & 1.99 & $<0.001$ & 0.004 & 0.28 \\
\hline & Goat & 9.4 & 22.4 & 16.6 & & & & \\
\hline \multirow[t]{2}{*}{$\mathrm{g} / \mathrm{kg}$ digestible $\mathrm{OM}$ intake $^{3}$} & Sheep & 8.5 & 14.0 & 13.4 & 1.01 & 0.001 & $<0.001$ & 0.42 \\
\hline & Goat & 2.9 & 10.8 & 7.9 & & & & \\
\hline
\end{tabular}

a,b Within a parameter and diet, means with different superscripts differ $(P<0.05)$. Superscripts are only shown when an AS $\times$ diet interaction $(P<0.05)$ was detected. ${ }^{1} \mathrm{GRC}=70: 30$ grass hay:concentrate; $\mathrm{ALC}=70: 30$ alfalfa hay:concentrate; $\mathrm{CAL}=70: 30$ concentrate:alfalfa hay.

${ }^{2}$ When an AS $\times$ diet interaction $(P<0.05)$ was detected, differences between AS were analyzed independently for each diet. The $P$-values of ANOVA for GRC, ALC, and CAL diets were $0.01,0.02$, and 0.008 for urinary $\mathrm{N}$ excretion $(\mathrm{g} / \mathrm{d})$, and $0.42,0.03$, and 0.38 for fecal $\mathrm{N}(\%$ of $\mathrm{N}$ intake), respectively.

${ }^{3}$ Calculated from OM intake and apparent total tract OM digestibility (values in Table 2).

decreased $\mathrm{N}$ retention observed in goats (Antoniou and Hadjipanayiotou, 1985), but endogenous losses were not measured in our study. In agreement with our results, some (Antoniou and Hadjipanayiotou, 1985; Al Jassim et al., 1991; Isac et al., 1994) have reported reduced N retention in goats than in sheep, although others reported no differences (Gihad, 1976; Jetana, 2005; Yáñez-Ruiz and Molina-Alcaide, 2007, 2008) or greater $\mathrm{N}$ retention in goats than in sheep (Bohra, 1980). However, no relation between diet quality and observed interspecies differences could be easily made from the results of these studies. These contrasting results might be partly due to the different breeds of animals used, as breed differences in $\mathrm{N}$ use have been reported both in sheep (Ranilla et al., 1997; 1998) and goats (Devendra, 1989).

\section{Urinary Excretion of Purine Derivatives}

The urinary PD excretion has been widely used as a method of estimating MNF to the duodenum in ruminants, but only a few studies have compared the PD excretion in sheep and goats fed the same diets. In our study, goats showed a greater mean excretion of allantoin $(P=0.01)$ but a lower mean excretion of xanthine $(P=0.008)$ and hypoxanthine $(P=0.007)$ compared with sheep, either expressed as $\mu \mathrm{mol} / \mathrm{kg} \mathrm{BW}^{0.75}$ (Table 5) or $\mathrm{mmol} / \mathrm{d}$ (data not shown). Despite of the differences in the excretion of individual PD, the total amount of PD excreted daily was similar in sheep and goats, either expressed as $\mu \mathrm{mol} /$ $\mathrm{kg} \mathrm{BW}^{0.75}$ (mean values averaged across diets of 592 and $659 \mu \mathrm{mol} / \mathrm{kg} \mathrm{BW}^{0.75}$, respectively; $P=0.26$; Table 5) or as mmol/d (mean values of 11.6 and $11.7 \mathrm{mmol} / \mathrm{d}$, respectively; $P=0.95$ ). The lack of animal species differences in total PD excretion is in agreement with the similar N intake ( $\mathrm{g} / \mathrm{d}$; Table 4) observed in both AS.

Allantoin represented between $73.4 \%$ and $73.8 \%$ of total urinary PD in sheep and between $87.3 \%$ and $90.8 \%$ in goats, which is in agreement with previous results in sheep (Ranilla et al., 1998; Carro et al., 2000; Giraldo et al., 2008) and goats (Yáñez-Ruiz et al., 2004ab; Jetana, $2005)$. The proportion of allantoin was not affected $(P$ $=0.92)$ by diet, but it was greater $(P<0.001)$ in goats compared with sheep for all diets. In contrast, goats had decreased proportions of xanthine $(P=0.003)$ and hypoxanthine $(P=0.003)$ than sheep. An AS $\times$ diet interaction $(P=0.03)$ was detected for uric acid and values were reanalyzed by diet, but there were no differences between sheep and goats in uric acid excretion for any $\operatorname{diet}(P=0.53,0.10$, and 0.19 for GRC, ALC, and CAL, respectively). Greater daily mean allantoin excretions in 
Table 5. Effects of animal species (AS) and dietary treatments on daily urinary excretion of purine derivatives (PD) and estimates of microbial $\mathrm{N}$ flow in sheep and goats $(\mathrm{n}=4)$

\begin{tabular}{|c|c|c|c|c|c|c|c|c|}
\hline \multirow[b]{2}{*}{ Item } & \multirow[b]{2}{*}{ AS } & \multicolumn{3}{|c|}{ Diet $^{1}$} & \multirow[b]{2}{*}{ SEM } & \multicolumn{3}{|c|}{$P$-value } \\
\hline & & GRC & ALC & CAL & & AS & Diet & AS $\times$ diet \\
\hline \multicolumn{9}{|l|}{$\overline{\mathrm{PD}, \mu \mathrm{mol} / \mathrm{kg} \mathrm{BW} \mathrm{BW}^{0.75}}$} \\
\hline Allantoin & Goat & 440 & 636 & 680 & & & & \\
\hline \multirow[t]{2}{*}{ Xanthine } & Sheep & 50.0 & 38.0 & 86.5 & 9.72 & 0.008 & 0.05 & 0.20 \\
\hline & Goat & 5.0 & 12.5 & 22.8 & & & & \\
\hline Hypoxanthine & Goat & 15.7 & 22.2 & 51.2 & & & & \\
\hline \multirow[t]{2}{*}{ Uric acid } & Sheep & 32.0 & 31.5 & 36.2 & 3.97 & 0.68 & 0.06 & 0.03 \\
\hline & Goat & 23.0 & 43.2 & 24.7 & & & & \\
\hline \multirow[t]{2}{*}{ Total PD } & Sheep & 518 & 562 & 697 & 52.4 & 0.26 & 0.006 & 0.24 \\
\hline & Goat & 484 & 714 & 778 & & & & \\
\hline \multicolumn{9}{|c|}{ Microbial $N$ flow (MNF), g/d ${ }^{2}$} \\
\hline MNF-LAB & Goat & 6.9 & 11.4 & 14.1 & & & & \\
\hline \multirow[t]{2}{*}{ MNF-SAB } & Sheep & 10.4 & 10.1 & 12.7 & 1.24 & 0.63 & 0.02 & 0.10 \\
\hline & Goat & 7.9 & 13.7 & 15.2 & & & & \\
\hline \multirow[t]{2}{*}{ MNF-LAB+SAB } & Sheep & 9.7 & 10.2 & 13.4 & 1.20 & 0.88 & 0.008 & 0.12 \\
\hline & Goat & 7.4 & 12.5 & 14.7 & & & & \\
\hline
\end{tabular}

\footnotetext{
${ }^{1} \mathrm{GRC}=70: 30$ grass hay:concentrate; $\mathrm{ALC}=70: 30$ alfalfa hay:concentrate; $\mathrm{CAL}=70: 30$ concentrate:alfalfa hay.

${ }^{2}$ MNF-RM: estimated from total PD excretion as described by Balcells et al. (1991) and Belenguer et al. (2002) for sheep and goats, respectively. MNF-LAB, MNF-SAB, and MNF-LSAB: estimated from total PD excretion, assuming values of urinary recovery of absorbed purines as PD of 0.802 for sheep and 0.760 for goats, and PB:N ratios obtained in the present study for LAB (MNF-LAB), SAB (MNF-SAB), or the average value from MNF-LAB and MNF-SAB (MNF-LSAB). $\mathrm{RM}=$ regression model; $\mathrm{LAB}=$ liquid associated bacteria; $\mathrm{SAB}=$ solid associated bacteria.
}

goats than in sheep when both were fed the same diets have also been found by Yáñez-Ruiz et al., (2004a) and Jetana (2005), but no interspecies differences were found by others (Yáñez-Ruiz et al., 2004b; Fujihara et al., 2007). Jetana (2005) speculated that the observed AS differences might be due to greater xanthine oxidase activities in tissues of goats compared with sheep. Xanthine oxidase degrades xanthine and hypoxanthine to uric acid and allantoin before excretion in urine. However, the lack of differences between animals of the 2 species in xanthine oxidase activities in the liver and small intestine observed by Jetana (2005) did not confirm his hypothesis. In the study of Jetana (2005), animals were fed low quality diets, but PB metabolism may be affected by the quality of the diet. This point deserves further investigation, as it has been suggested that others factors, such as physiological status, may have an effect on the metabolism of PB (Mota et al., 2008).

\section{Estimations of Microbial Nitrogen Flow}

Estimated MNF mean values using the different calculation procedures are shown in Table 5. All procedures detected significant effects of diets $(P=0.004$ to $0.02)$ on $\mathrm{MNF}$ and there were no AS $\times$ diet interactions $(P=0.10$ to 0.30$)$ for any procedure. The use of RM re- sulted in greater $(P=0.008)$ MNF values in sheep compared with goats (averaged across diets, 11.2 and $8.5 \mathrm{~g} / \mathrm{d}$, respectively), whereas no differences between AS were detected by the other procedures ( $P=0.38$ to 0.88$)$. This was due to the reduced variability in the values obtained by using RM in comparison with those obtained by the rest of procedures, as revealed by the reduced SEM of the statistical analysis (Table 6).

In sheep, MNF-LAB, MNF-SAB, and MNF$\mathrm{LAB}+\mathrm{SAB}$ values were similar $(P=0.42,0.89$, and 0.71 , respectively) to those obtained by using the RM. On the contrary, MNF-LAB and MNF-SAB mean values in goats were greater $(P=0.001$ and $<0.001$, respectively) than those obtained by using RM. And, MNFLAB + SAB values overestimated $(P<0.001)$ MNF-RM values by $1.20,1.34$, and 1.44 for diets GRC, ALC, and CAL, respectively. The results indicate that there was a better agreement between procedures for MNF estimation in sheep compared with goats and underlines the importance of using a representative bacterial pellet for each animal and diet to calculate MNF. Two studies (Balcells et al., 1991; Chen et al., 1992) have been conducted in sheep to develop a similar RM. Just 1 study with only 3 animals (Belenguer et al., 2002) has been conducted in nonproducing goats. Values from RM for sheep fitted well with those estimated from PB:N ratio 
in bacterial pellets in our study, but values from RM in goats were lower than those obtained from $\mathrm{PB}: \mathrm{N}$ ratio of bacterial pellets in our study. As pointed out by Chen and Ørskov (2004), more studies in goats are needed.

In conclusion, some differences in digestibility and ruminal fermentation were found between sheep and goats fed medium to good quality diets. Significant AS $\times$ diet interactions were observed for some variables, indicating that interspecies differences are influenced by the diet type. In general, differences between sheep and goats were more pronounced for the medium quality diet compared with those of the high quality diet. The most marked differences were observed in $\mathrm{N}$ balance and urinary PD excretion. For all diets, sheep retained more $\mathrm{N}$ compared with goats. This was mainly due to the greater urinary losses in goats, which was observed for all diets, whereas fecal excretion was similar for both AS fed 2 of the experimental diets. These AS differences in urinary $\mathrm{N}$ losses would indicate a greater contribution of goats to $\mathrm{N}$ environmental contamination compared with sheep. There were no interspecies differences in total PD excretion, but sheep excreted less allantoin and more xanthine and hypoxanthine compared with goats. When using urinary PD excretion to estimate MNF, in sheep there was a close agreement between the values of MNF estimated with RM of Balcells et al. (1991) and those estimated using PB:N ratios in the pellets isolated in our study. In contrast, in goats the use of RM of Belenguer et al. (2002) underestimated the MNF values obtained by using the bacterial pellets as reference. More studies to assess the possible differences between sheep and goats in endogenous PD excretion, renal clearance of absorbed PB, etc. are needed to improve the estimations of MNF from PD excretion.

\section{LITERATURE CITED}

Al Jassim, R. A. M., S. A. Hassan, A. N. Al-Ani, and T. K. Dana. 1991. Effects of undegradable protein supplementation on digestion and nitrogen balance in sheep and goats. Small Rum. Res. 5:57-63.

Antoniou, T., and M. Hadjipanayiotou. 1985. The digestibility by sheep and goats of five roughages offered alone or with concentrates. J. Agric. Sci. 105:663-671.

Balcells, J., J. A. Guada, C. Castrillo, and J. Gasa. 1991. Urinary excretion of allantoin and allantoin precursors by sheep after different rates of purine infusion into the duodenum. J. Agric. Sci. 116:309-317.

Belenguer, A., D. R. Yáñez, J. Balcells, N. H. Ozdemir Baber, and M. González Ronquillo. 2002. Urinary excretion of purine derivatives and prediction of rumen microbial outflow in goats. Livest. Prod. Sci. 77:127-135.

Bohra, H.C. 1980. Nutrient utilization of Prosopis cineraria (Khejri) leaves by desert sheep and goats. Ann. Arid Zone 19:73-81.
Carro, M. D., C. Valdés, M. J. Ranilla, and J. S. González. 2000. Effect of forage to concentrate ratio in the diet on ruminal fermentation and digesta flow kinetics in sheep. Anim. Sci. 70:127-134.

Chen, X. B., Y. K. Chen, M. F. Franklin, E. R. Ørskov, and W. J. Shand. 1992. The effect of feed intake and body weight on purine derivative excretion and microbial protein supply in sheep. J. Anim. Sci. 70:534-1542.

Chen, X.B., and E.R. Ørskov. 2004. Research on urinary excretion of purine derivatives in ruminants: Past, present and future. Pages 180-210 in Estimation of Microbial Protein Supply in Ruminants Using Urinary Purine Derivatives. FAO/IAEA. H. P. S. Makkar and X. B. Chen, ed. Kluwer Academic Publishers, Vienna, Austria.

Chen, X. B., E. R. Ørskov, and F. D. DeB. Hovell. 1990. Excretion of purine derivatives by ruminants: Endogenous excretion, differences between cattle and sheep. Br. J. Nutr. 63:121-129.

Devendra, C. 1989. Comparative aspects of digestive physiology and nutrition in goats and sheep. Pages 45-60 in Ruminant Physiology and Nutrition in Asia. C. Devendra and E. Imaizumi, ed. Jap. Soc. Zootech. Sci., Sendai, Japan.

Domingue, B. M. F., D. W. Dellow, P. R. Wilson, and T. N. Barry. 1991. Nitrogen metabolism, rumen fermentation and water absorption in red deer, goats and sheep. New Zealand J. Agric. Res. 34:391-400.

Doyle, P. T., J. K. Egan, and A. J. Thalen. 1984. Intake, digestion and nitrogen and sulfur retention in Angora goats and Merino sheep fed herbage diets. Austr. J. Exp. Anim. Sci. 24:165-169.

Fujihara, T., M. N. Shem, and T. Matsui. 2007. Urinary excretion of purine derivatives and plasma allantoin level in sheep and goats during fasting. Anim. Sci. J. 78:129-134.

García, M. A., M. D. Isac, J. F. Aguilera, and E. Molina Alcaide. 1994. Rumen fermentation pattern in goats and sheep grazing pastures from semiarid Spanish unsupplemented or supplemented with barley grain or barley grain-urea. Livest. Prod. Sci. 39:81-84.

Gihad, E. A. 1976. Intake, digestibility and nitrogen utilization of tropical natural grass hay by goats and sheep. J. Anim. Sci. 43:879-883.

Giraldo, L. A., M. L. Tejido, M. J. Ranilla, S. Ramos, and M. D. Carro. 2008. Influence of direct-fed fibrolytic enzymes on diet digestibility and ruminal activity in sheep fed a grass hay-based diet. J. Anim. Sci. 86:1617-1623.

Isac, M. D., M. A. García, J. F. Aguilera, and E. Molina-Alcaide. 1994. A comparative study of nutrient digestibility, kinetics of digestion and passage and rumen fermentation pattern in goats and sheep offered medium quality forages at the maintenance level of feeding. Arch. Tierernahr. 46:37-50.

Jetana, T. 2005. Urinary purine derivatives as index for estimation of rumenal microbial nitrogen production in sheep and goats. $\mathrm{PhD}$ Diss. University Putra Malaysia, Malaysia.

Li, D., X. Houa, Y. Liu, and Y. Liu. 2008. Effect of diet composition on digestion and rumen fermentation parameters in sheep and cashmere goats. Anim. Feed Sci. Technol. 146:336-344.

Martín-Orúe, S. M., J. Balcells, J. A. Guada, and C. Castrillo. 1995. Endogenous purine and pyrimidine derivative excretion in pregnant sows. Br. J. Nutr. 73:375-385.

Molina Alcaide, E., M. A. García, and J. F. Aguilera. 1997. The voluntary intake and rumen digestion by grazing goats and sheep of a low-quality pasture from a semi-arid land. Livest. Prod. Sci. 52:39-47. 
Molina Alcaide E., Martín García A. I., Aguilera J. F. 2000. A comparative study of nutrient digestibility, kinetics of degradation and passage and rumen fermentation pattern in goats and sheep offered good-quality diets. Livest. Prod. Sci. 64:215-223

Molina-Alcaide, E., E. Y. Morales-García, A. I. Martín-García, H. Ben Salem, A. Nefzaoui, and M. R. Sanz-Sampelayo. 2010. Effects of partial replacement of concentrate with feed blocks on nutrient utilization, microbial $\mathrm{N}$ flow, and milk yield and composition in goats. J. Dairy Sci. 93:2076-2087.

Mota, M., J. Balcells, N. H. Ozdemir Baber, S. Bölüktepe, and A. Belenguer. 2008. Modelling purine derivative excretion in dairy goats: Endogenous excretion and the relationship between duodenal input and urinary output. Animal 2:44-51.

NRC (National Research Council). 1985. Subcommittee on Nitrogen Usage in Ruminants. Ruminant Nitrogen Usage. The National Academies Press, Washington DC, USA.

NRC (National Research Council). 2007. Committee on the Nutrient Requirements of Small Ruminants. Nutrient Requirements of Small Ruminants: Sheep, Goats, Cervids, and New World Camelids. The National Academies Press, Washington DC, USA.

Prieto, C., J. F. Aguilera, L. Lara, and J. Fonoll. 1990. Protein and energy requirements for maintenance of indigenous Granadina goats. Br. J. Nutr. 63:155-163.

Ranilla, M. J., and M. D. Carro. 2003. Diet and procedures used to detach particulate-associated microbes from ruminal digesta influence chemical composition of microbes and estimation of microbial growth in Rusitec fermenters. J. Anim. Sci. 81:537544.

Ranilla, M. J., M. D. Carro, C. Valdés, F. J. Giráldez, and S. López. 1997. A comparative study of ruminal activity in Churra and Merino sheep offered alfalfa hay. Anim. Sci. 65:121-128.
Ranilla, M. J., M. D. Carro, C. Valdés, and J. S. González. 2001. The digestion and digesta flow kinetics in sheep and goats fed two different diets. Options Mediterranéennes, Series A. 59:61-65.

Ranilla, M. J., S. López, F. J. Giráldez, C. Valdés, and M. D. Carro. 1998. Comparative digestibility and digesta flow kinetics in two breeds of sheep. Anim. Sci. 66:389-396.

Tamminga, S. 1996. A review on environmental impacts of nutritional strategies in ruminants. J. Anim. Sci. 74:3112-3124.

Tsiplakou, E., I. Hadjigeorgiou, K. Sotirakoglou, and G. Zervas. 2011. Differences in mean retention time of sheep and goats under controlled feeding practices. Small Rum. Res. 95:48-53.

Yáñez-Ruiz, D. R., A. I. Martín-García, A. Moumen, and E. MolinaAlcaide. 2004a. Ruminal fermentation and degradation patterns, protozoa population, and urinary purine derivatives excretion in goats and wethers fed diets based on two-stage olive cake: Effect of PEG supply. J. Anim. Sci. 82:2023-2032.

Yáñez-Ruiz, D. R., A. I. Martín-García, A. Moumen, and E. MolinaAlcaide. 2004b. Ruminal fermentation and degradation patterns, protozoa population and urinary purine derivatives excretion in goats and wethers fed diets based on olive leaves. J. Anim. Sci. 82:3006-3014.

Yáñez-Ruiz, D. R., and E. Molina-Alcaide. 2007. A comparative study of the effect of two-stage olive cake added to alfalfa on digestion and nitrogen losses in sheep and goats. Anim. 1:227-232.

Yáñez-Ruiz, D. R., and E. Molina-Alcaide. 2008. A comparative study of nutrients utilization, alkaline phosphatase activity and creatinine concentration in the serum of sheep and goats fed diets based on olive leaves. J. Anim. Physiol. Anim. Nutr. 92:141-148. 
References

This article cites 32 articles, 6 of which you can access for free at: http://www.journalofanimalscience.org/content/90/11/3963\#BIBL 